\title{
Uses of a Pandemic: Forging the Identities of Influenza and Virus Research in Interwar Britain
}

\author{
Michael Bresalier*
}

\begin{abstract}
Summary. This paper counters the tendency to retrospectively viralise the 1918-19 pandemic and to gloss the important historiographical point that, in Britain, such knowledge was in-the-making between 1918 and 1933. It traces the genesis of influenza's virus identity to British efforts in 1918-19 to specify the cause of the pandemic and it examines how, in the 1920s, the British Medical Research Council used the connection between a virus and the pandemic to justify the development of virus research and to make influenza a core problem around which it was organised. It shows that the organisation of medical virus research was inextricably linked to the pandemic before the actual discovery of flu virus in 1933. Recognising that the relationship between the virus and the disease itself has a history demands we rethink the pandemic's medical scientific legacy and the crucial role of virus research in shaping its history.
\end{abstract}

Keywords: 1918-19 influenza pandemic; Medical Research Council; virus research; interwar scientific medicine; experimental pathology

In May 1922, Walter Morley Fletcher, Secretary of the Medical Research Council (MRC), organized a secret meeting of pathologists at the War Office to outline a new scheme of research on 'diseases probably caused by filter-passing organisms." Created in 1913, the MRC had used the war to apply laboratory science to military medicine. In peace time it was seeking new challenges and the still relatively unexplored filter-passing organisms offered just such opportunities, for medical science and the health of the nation. An immediate reason for the MRC's interest was the 1918-19 influenza pandemic. In his Annual Report for 1921-22, Fletcher stressed that investigations during the pandemic of the purported connection between a filter-passer and influenza were a key motivation for the new scheme.

There could hardly be a set of problems whose solution has more potential importance for the community than this. Influenza kills regularly, though its slaughter is chiefly effected during epidemics. In a few months in 1918-19 it killed more persons in India than died from the plague there during the previous twenty years ....2

*Centre for the History of Science, Technology, and Medicine, University of Manchester, Second Floor, Simon Building, Room 2.67, Brunswick Street, Manchester M13 9PL, UK. E-mail: michael.bresalier@manchester.ac.uk Michael Bresalier is a Research Associate at the Centre for the History of Science, Technology, and Medicine, University of Manchester. He has published on the history of influenza, virus research and military medicine in Britain. $\mathrm{He}$ is working on a manuscript, 'Globalizing Flu: Post-War International Health and the Politics of an Emerging Disease', which examines the problem of access to biomedical resources and vaccines in infectious disease control.

\footnotetext{
${ }^{1}$ National Archives, Kew, Surrey (hereafter NA), FD1/

${ }^{2}$ MRC 1923, p. 12.
} 1279 Research into Diseases Probably Caused by Filterable Viruses, 3 May 1922. 
The pandemic had ignited interest in the nature of filterable viruses, however, the way forward was unclear, as Fletcher observed: 'The chief problem which the investigator of [filterable viruses] meets is the difficulty of proceeding by sound experimental methods. ${ }^{3}$ The purported influenza agent was one of a group of pathogens that could not be seen with light microscopes or studied by the culture methods that had been so successful with bacteria. Only their pathogenic effects were evident in animal models and could be traced by serological tests. The MRC's new scheme was to build on these methods to make viruses into workable laboratory objects and to develop new methods for their control.

This paper traces how, in the decade after 1918, the pandemic and virus research became inextricably linked in the work supported by the MRC. Fletcher and his colleagues became convinced that if questions about influenza's virus identity-and more general questions about virus diseases-were to be successfully investigated new researchers and institutions would have to be created. The 1922 plan charged the Council's flagship laboratory, the National Institute for Medical Research (NIMR), with, among its primary goals, developing research on human and animal virus diseases and linking virus researchers to medical and veterinary institutions. ${ }^{4}$ Work on the influenza filter-passer was pivotal.

British medical science played an important role in the battle against the pandemic, but it was also shaped by it. Donald Fisher has argued that the pandemic represented a 'central turning point' in efforts to modernize British medicine: 'the death of millions of persons as a result of influenza made the advancement of medical knowledge and practice urgent. ${ }^{5}$ According to Fisher, the pandemic prompted the British state to take a new role in medical scientific administration and education, primarily through the MRC. ${ }^{6}$ The MRC's collaboration with the Rockefeller Foundation to reform British medical education was an important legacy. But the pandemic reached into the very organization of medical scientific research. The MRC's virus research scheme clearly demonstrates this point. Fletcher regularly invoked the idea that a filterable virus might have caused the greatest pandemic since the Black Death to bolster support for the scheme. More than a symbolic resource, the identities of the pandemic and virus research were forged together as part of broader MRC plans to scientifically modernise pathology. ${ }^{7}$ Experience during the war and the pandemic convinced Fletcher and his colleagues that pathology needed to be founded on experimental principles, and located above all in university science departments and research institutions. ${ }^{8}$ The NIMR emerged as one of the key institutional supports for this new pathology, and virus research became closely allied to its development.

My argument takes up Roger Cooter's recent challenge to historicise the relationship between war and epidemics. Cooter claims, rightly I believe, that medical historians have taken this relationship as self-evident. ${ }^{9}$ This is true of much work on the 1918-19 pandemic, which has retrospectively linked influenza's emergence and virulence to specific war conditions. ${ }^{10}$ Such approaches are important but fail to highlight how this relationship was understood and used by contemporary actors, particularly those involved in

\footnotetext{
${ }^{3}$ MRC 1923, p. 12.

${ }^{4}$ Thomson 1973, 1975, pp. 114-29.

${ }^{5}$ Fisher 1978a, p. 26.

${ }^{6}$ Alter 1987, p. $172 \mathrm{ff}$.
}

\footnotetext{
${ }^{7}$ Austoker 1989, p. 39; Thomson 1975, p. 114.

${ }^{8}$ Lawrence 2006, pp. 11-23.

${ }^{9}$ Cooter 2003.

${ }^{10}$ For example, Oxford 2001, Tanner 2002, Brown 2003, and Byerly 2005.
} 
generating medical knowledge. My analysis critically examines ways in which the epidemic-and-war couplet was constructed through laboratory practices and their institutional organisation during and after the pandemic. In Britain the mobilisation of the military medical machine against the pandemic bound the disease to the war. ${ }^{11}$ Especially important were military pathology investigations, supported by the War Office and MRC, into the bacteriology of the pandemic and, in due course, into the role of a 'filterable virus'. These investigations not only connected the pandemic to a filterable virus; they also connected virus research to the wartime organisation of pathology. Both were used by the MRC as a rationale for developing virus research in the 1920s.

By tracing this process, my account counters the ahistorical tendency to retrospectively viralise the pandemic. Ever since a virus was established as influenza's primary cause in 1933, virologists and historians have used it to explain many aspects of the pandemic. ${ }^{12}$ Such histories tend to gloss the important historiographical point that such knowledge was in-the-making between 1918 and 1933, so that there has been a tendency to ignore the historicity of the relationship between influenza, the pandemic and virus research. To properly situate the making and uses of medical knowledge of the pandemic it is important recognize that this relationship has a history that goes right back to the pandemic itself.

\section{Pandemic Germs}

Few histories of the pandemic explore its contemporary microbiology. ${ }^{13}$ Historians now know that it struck Britain in three distinctive waves. A relatively mild epidemic beginning in early spring 1918 was quickly followed by a lethal autumn epidemic after which developed a somewhat less virulent epidemic in spring 1919. An estimated 250,000 died, with most succumbing in autumn $1918 .{ }^{14}$ While each wave presented its own clinical and epidemiological characteristics, retrospective accounts have linked them together into a single cataclysmic pandemic.

At the time, however, the identities and relationship between the waves baffled medical experts. The summer epidemic shared characteristics with previous visitations, particularly that of 1889-90, with doctors describing extreme body aches, prostration, fever, sore throat, dry cough, nausea and general lassitude in most patients. Yet important aspects did not fit the established picture. Much confusion stemmed from uncertainties about its aetiology. Between early spring and late autumn 1918, a loose bacteriological consensus built before the war fragmented, with competing pathologists and physicians backing different pathogens.

Resolving the aetiological problem was imperative to official pandemic strategies. The War Office, Army Medical Service, and MRC prioritised identifying the suspected influenza germ and developing preventive measures-particularly, vaccines-to control it. These strategies were initially based on the assumption that the germ was Bacillus influenzae, an organism first identified in 1891 by the Berlin bacteriologists, Richard Pfeiffer and

\footnotetext{
${ }^{11}$ Bresalier 2011.

${ }^{12}$ Burnet and Clark 1942; Morens and Taubenberger 2009.

${ }^{13}$ Tognotti 2003.

${ }^{14}$ Langford 2002, Johnson and Mueller 2002.
} 
Shibashuro Kitasato. ${ }^{15}$ Pfeiffer developed special methods for its cultivation, which, he found, required a substrate of blood-in particular, haemaglobulin. ${ }^{16}$ He promoted the bacillus as the primary cause of influenza and his blood-agar culture technique as necessary for establishing it.

Identification of the germ became widely accepted as the best way to distinguish 'true influenza' from other influenza-like conditions. In Britain, Pfeiffer's claims were first substantiated in 1893 by E. E. Klein, a founder of British bacteriology, in investigations for the Medical Department of the Local Government Board (LGB). ${ }^{17}$ Pfeiffer's techniques were slowly incorporated into bacteriological practice and 'Pfeiffer's bacillus' gained standing as the 'germ of influenza'. ${ }^{18}$ Both became part of the general organization of pathology for war. ${ }^{19}$

British approaches to the pandemic were elaborated within the contexts of military medicine, and defined by military imperatives. ${ }^{20}$ Like all facets of British society, medicine had been mobilised for total war. Over half the medical profession was eventually enlisted, along with many hospitals. Medical science was also mobilised and the MRC played a vital role in its coordination. Most important for the subsequent fight against influenza, Fletcher worked closely with William Boog Leishman, Advisor on Pathology to the War Office, to link pathological laboratories to base and field hospitals in France and Flanders. ${ }^{21}$ Organised to collect, identify, and control pathogens, military pathology delivered therapeutic and preventive measures against a range of battlefield diseases, and its planners trusted that it could do the same with influenza. ${ }^{22}$

Signs of the spring wave were first encountered in military garrisons in France and Flanders in March 1918. The epidemic perplexed medical authorities. It occurred in late spring instead of autumn. Rather than the usual susceptible groups-the very young, aged, and infirm -it affected soldiers in the prime of life. ${ }^{23}$ Few typical symptoms were evident. ${ }^{24}$ But most importantly, when pathologists ran bacteriological tests they rarely found $B$. influenzae.

So seldom were pathologists' efforts successful that many concluded that $B$. influenzae was at best associated with, but not essential to, the epidemic. Bacteriological evidence did not support classifying the epidemic as influenza. Rather, it generated controversy. Through the summer of 1918, two camps of pathologists clashed over the causal agent: the 'Pfeiffer school' argued that the epidemic was influenza, and attributed failures to find $B$. influenzae to technical failures; the 'anti-Pfeiffer school' argued that its absence indicated either that the epidemic was not influenza or that influenza was caused by another organism. ${ }^{25}$ They proposed a range of known bacteria, including streptococci, staphylococci, and streptodipplococci. But no one could agree which played the primary role.

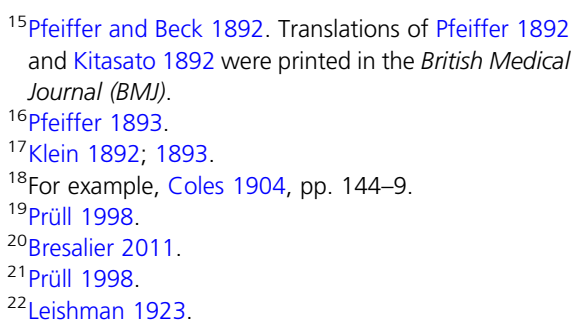

\footnotetext{
${ }^{23}$ Tanner 2002, p. 54.

${ }^{24}$ Abrahams et al. 1919; French 1919.

${ }^{25}$ Ludwik Rajchman, editor of the MRC's Medical Supplement, used the term 'Pfeiffer school' those who believed that 'true influenza epidemics' were caused only by $B$. influenzae, 'Influenza', Medical Supplement, 1 October 1918, p. 354. Fildes and Mclntosh 1920, p. 119, used the term 'anti-Pfeiffer school' to describe its critics.
} 
This situation jeopardised official prevention strategies. Without an agreed agent against which to develop a specific vaccine, army medical authorities decided to produce a 'mixed' vaccine, which incorporated bacteria associated with secondary complications, including $B$. influenzae. ${ }^{26}$ Generally viewed as unsatisfactory, the decision added official backing to doubts about Pfeiffer's bacillus. ${ }^{27}$ These doubts also prompted Leishman and his colleagues to organise research into other agents. ${ }^{28}$ Fletcher argued that, 'on the hypothesis that B. influenzae, no less than pneumococci and streptococci, are secondary [infections]', official strategy would be better served by exploring the possible role a so-called 'filter-passing virus. ${ }^{.29}$ In November 1918, the MRC and the War Office put in train a 'search for an unrecognized virus'. ${ }^{30}$

Little was known about the basic nature of filter-passing viruses. The category only emerged at the turn of the century, when it became popular among some bacteriologists as a way to explain diseases for which causes could not be ascertained by standard bacteriological methods. ${ }^{31}$ Filter-passing viruses were operationally defined by the fact that they were neither retained by standard bacteriological filters, nor susceptible to cultivation on artificial media, nor visible by available methods of light microscopy. ${ }^{32} \mathrm{~A}$ pathogen was characterised as filterable when clinical material passed through the smallest of available filters still induced disease in a host. ${ }^{33}$ The new category included a number of important human and animal diseases: foot-and-mouth, fowl pox, rabies, swine fever, measles and poliomyelitis. ${ }^{34}$

The first filterable virus theory of influenza was proposed in 1914 by the German bacteriologist, Wilhelm Kruse, in studies of the common cold. ${ }^{35}$ British interest grew in 1918 as a possible explanation for bacteriological failures. Between October and December 1918, the MRC helped S. L. Cummins, Advisor in Pathology to the AMS, organise filterpasser studies in Abbeville, Flanders and Etaples, France. ${ }^{36}$ Major Howard Graeme Gibson led the Abbeville team. ${ }^{37}$ With Major F. B. Bowman and Captain J. I. Connor, Gibson's team followed the work of two French bacteriologists, Charles Nicolle and Charles Lebailly, who claimed in early 1918 that they had discovered a filter-passer. As proof, Nicolle and Lebailly reported that they had reproduced the disease in healthy monkeys and men by serial inoculation of filtered bronchial secretions from infected cases. ${ }^{38}$ Seeking to repeat these experiments, Gibson's team relied on the MRC for expertise and materials, including macaque monkeys and baboons shipped from London Zoo. ${ }^{39}$

Within weeks, Gibson reported that his team had isolated a filterable agent and produced an experimental disease. ${ }^{40}$ In December 1918, they described how they had reproduced a characteristic lung haemorrhage in monkeys, similar to that seen in clinical cases,

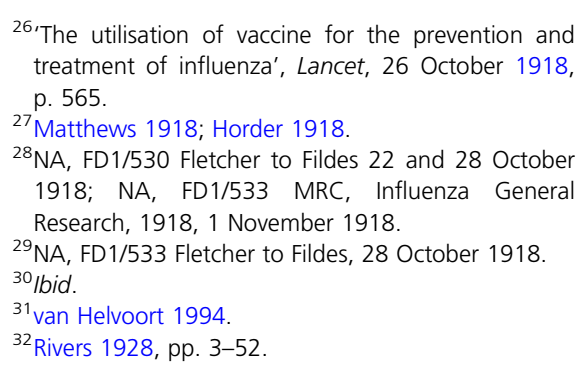

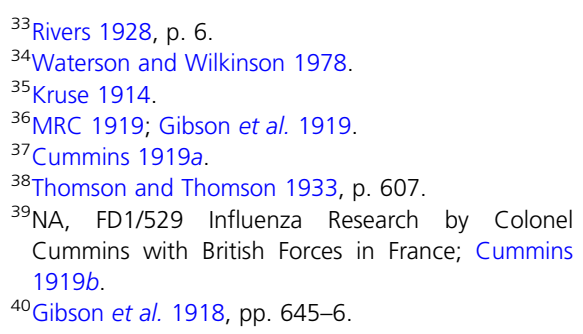

${ }^{33}$ Rivers 1928, p. 6.

${ }^{34}$ Waterson and Wilkinson 1978

${ }^{5}$ Kruse 1914

${ }^{37}$ Cummins $1919 a$.

${ }^{38}$ Thomson and Thomson 1933, p. 607.

${ }^{39} \mathrm{NA}$, FD1/529 Influenza Research by Colonel $1919 b$.

${ }^{40}$ Gibson et al. 1918, pp. 645-6. 


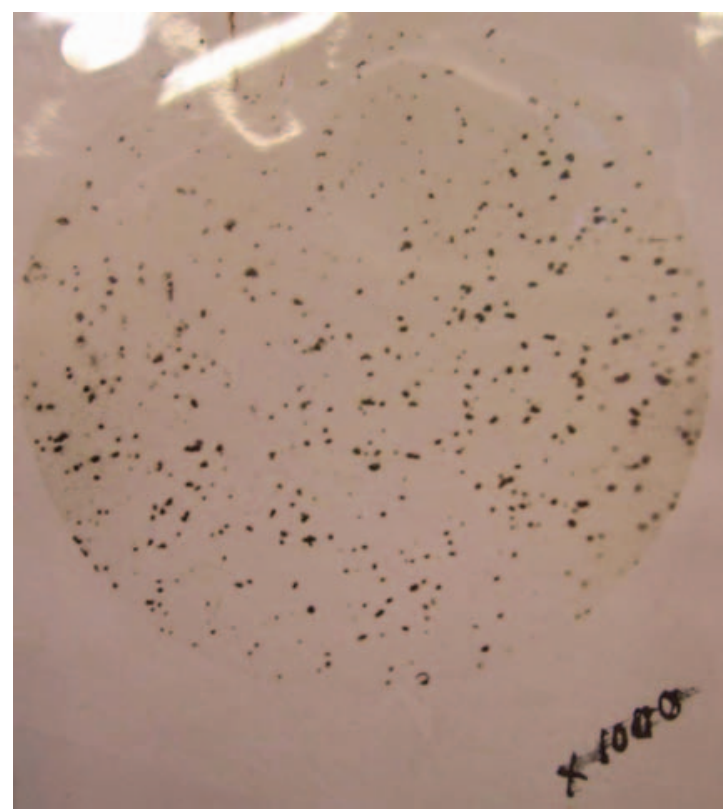

Fig. 1 Abbeville Filter-passer. Photomicrograph by the NIMR microscopist, J. E. Barnard. Source: NA FD1/529 Bowman to Fletcher, 11 February 1919.

and isolated and cultured minute 'coccoid bodies' from the tissue. Since the agent passed through filters and produced 'experimental influenzal' lesions, they reckoned that it was a 'filterable virus' and 'in all probability the cause of influenza' (Figure 1). ${ }^{41}$ Tragically, Gibson died from influenza, leaving the team's work unfinished, but not before pathologists at Etaples, headed by Major-General John Rose Bradford and Captain James Wilson, claimed to have isolated similar coccoid bodies (Figures 2 and 3). ${ }^{42}$

Although preliminary, the studies won support from The Lancet and the BMJ. Cummins argued that the 'two series of observations, carried out independently, should confirm each other, [and] greatly strengthen the case for the new organism. ${ }^{43}$ F. W. Andrewes, director of the Department of Pathology at St Bart's, who had assisted on Klein's 1893 investigations of Pfeiffer's bacillus, pointed to Gibson's experiments as providing the best evidence for the primary role of a filterable virus. ${ }^{44}$

These endorsements did not allay criticisms. In 1919, J. A. Arkwright, then working with the War Office on trench fever, levelled a devastating critique of the Etaples research. ${ }^{45}$ Arkwright demonstrated that the coccoid bodies were identical to those found in uninoculated tubes and that the cultures were contaminated with ordinary bacteria. In effect, the bodies were not pathogens, but either benign globoids or bacteria. This analysis forced Rose Bradford and Wilson to reconsider, and in a stunning move, they publicly retracted their claims. ${ }^{46}$

\footnotetext{
${ }^{41} \mathrm{lbid}$.

${ }^{42}$ Bradford et al. 1919, pp. 19-36.

${ }^{43}$ Gibson et al. 1919, p. 24.
}

\footnotetext{
${ }^{44}$ Andrewes 1920, pp. 110-25.

${ }^{45}$ Arkwright 1919, pp. 233-5.

${ }^{46}$ Arkwright 1919, pp. 236-7.
} 


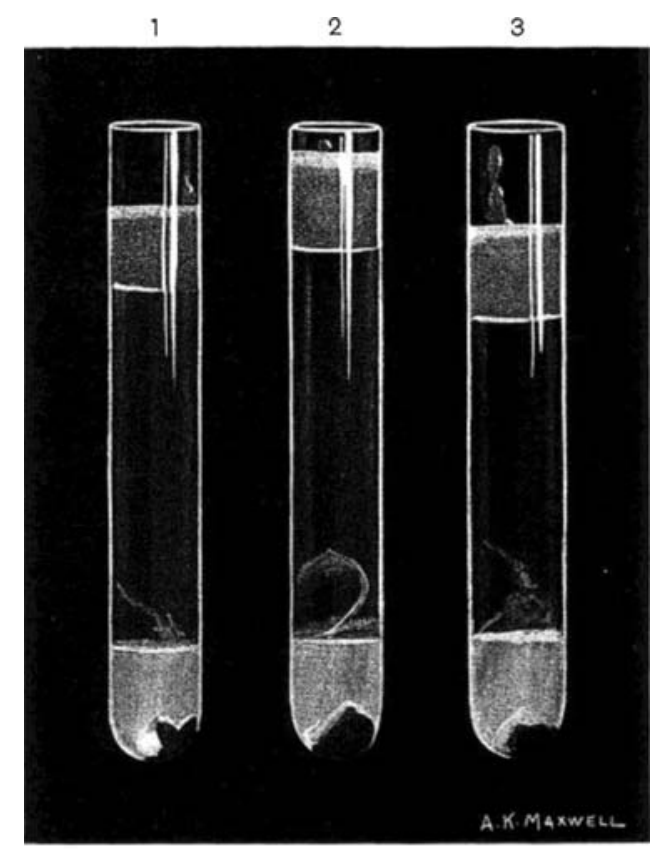

A. Influenza Virus.

(1) 3 days' growth.

(2) 5 days' growth.

(3) 7 days' growth.

Fig. 2 Etaples Filter-passer. Etaples workers' virus in Noguchi cultures at (1) 3 days' growth, (2) 5 days' growth, (3) 7 days' growth. The culture material was inoculated into guinea pigs and monkeys. Source: Bradford, Bashford and Wilson 1919b, p. 307.

Arkwright's criticisms coincided with renewed support for Pfeiffer's bacillus. In 1920, Paul Fildes and James Mclntosh, two leading London pathologists, published new evidence for its primary role and launched their own attack on the virus theory. ${ }^{47}$ Former colleagues at the London Hospital's Department of Bacteriology, they shared the view that the bacillus was the agent of the pandemic, and that new techniques made it possible to demonstrate its role. Mclntosh wrote:

[T]he epidemic can be divided into two stages, a first in which $B$. influenzae was seldom demonstrated, and a second, in which this bacillus was demonstrated with great regularity. This fact is not attributable to any alteration in the epidemic itself, but to the application of new methods for the demonstration of the bacillus of influenza. ${ }^{48}$

Most important among these techniques were 'selective media', which inhibited the overgrowth of cultures by other microorganisms. ${ }^{49}$ 


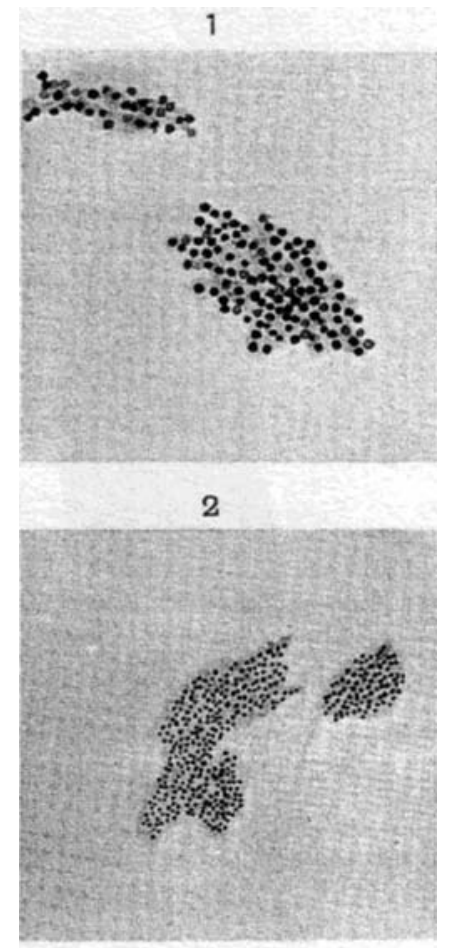

B. Culture from Sputum.

5 days' growth.

(I) $\frac{1}{10}$ in. obj. Baker.

(2) $\frac{1}{1}$ in. obj. Angus.

Fig. 3 Etaples Filter-passer Films. In films the organism had 'the appearance of a minute, rounded, or slightly oval, undifferentiated coccus-like body, arranged in colonies of twenty to sixty elements' Source: Bradford, Bashford and Wilson 1919b, p. 308.

Fildes and McIntosh argued that selective culture enabled them to establish a causal link between the bacillus and influenza. First, they could regularly identify the bacillus from large numbers of cases. Second, they could isolate it from broncho-pneumonia lesions clinically associated with the disease. Finally, they could use pure cultures to reproduce the disease in experimental animals. For Fildes and Mclntosh, the evidence generated with selective media was enough to counter the 'great revolt against the view ... that B. influenzae ... was the cause of the disease. ${ }^{, 50}$

Building on Arkwright's criticisms, they argued that filter-passing work was 'unconvincing'. ${ }^{51}$ Gibson's research was symptomatic of its shortcomings. Neither the identity of the virus nor its relationship to influenza had been demonstrated. ${ }^{52}$ Moreover, inoculation experiments on humans — of the kind used by Nicolle and Lebailly—-were easily discredited 
because, as other observers noted, researchers either failed to isolate subjects from previous infections or simply produced a different illness. ${ }^{53}$ The alleged filter-passer thus failed to meet any of Koch's postulates. Most damningly, they reckoned that researchers used the filter-passer as an alibi: 'the invisible virus concept absolves the discoverers from the necessity of producing evidence of a characteristic microbe. ${ }^{.54}$

These criticisms cast doubt on whether influenza's cause could ever be determined. In a 1922 review, the bacteriologist Robert Donaldson observed that there were no good empirical grounds to support either agent. ${ }^{55}$ While he agreed with criticisms of the filterable virus, he found little to support Pfeiffer's bacillus. While frequently found in post-mortem studies, most inoculation experiments failed to produce a characteristic lesion in laboratory animals. ${ }^{56}$ This strongly suggested that it was a secondary infection. Donaldson challenged the idea that a causal inference could be drawn from its apparently high incidence during the autumn epidemic. 'We are not at liberty to claim, that because an organism is always present, it is therefore necessarily the cause. ${ }^{57}$ Proponents of Pfeiffer's bacillus had mistaken an association for a cause.

Some critics took the conflicting aetiological claims as indication of the failure of bacteriologically-based approaches. ${ }^{58}$ Andrew Mendelshon has shown that a contingent of British physicians and epidemiologists used these conflicts to attack reductive approaches to disease causation and to promote multifactorial models to examine the role of hereditary and environmental factors in variations in the severity, incidence and susceptibility to infectious diseases. ${ }^{59}$ But while such models found support in epidemiology, pubic health and clinical medicine, the MRC countered them. Contrary to critics, official pandemic strategies were widely lauded. While war conditions may have contributed to the virulence of the epidemic, British mortality, in both the services and amongst civilians, was lower than in other countries. ${ }^{60}$ Fletcher insisted that the rapid organisation of coordinated strategies was testimony to the merits of military pathology. Translating military pathology's success into peace time became an MRC goal, and both the pandemic and virus research were enrolled in this mission. The pandemic highlighted the need for a new direction in laboratory pathology, towards filterable viruses. At the same time, virus research represented a way to preserve a specific aetiology as the guiding principle of pathological research and to counter challenges to the authority of laboratory medicine.

\section{Experimentalising Pathology}

MRC interest in virus research was intimately tied to its larger goal of modernising the organisation of basic sciences in medical training, practice and research. ${ }^{61}$ For Fletcher, the pandemic demonstrated the particular need to modernise pathology. ${ }^{62}$ This was not the old pathology of the mortuary, rather the microbiology-inspired enterprise, previously fostered in Germany and France, that linked aetiologies with patho-physiology and immunology, and focused preventive and therapeutic measures on them. While the

\footnotetext{
${ }^{53}$ Maitland et al. 1921.

${ }^{54}$ Fildes and Mclntosh 1920, p. 159.

${ }^{55}$ Donaldson 1922, pp. 139-213.

${ }^{56}$ Maitland and Cameron 1921, p. 492; Maitland et al. 1921.

${ }^{57}$ Donaldson 1922, p. 158.
}

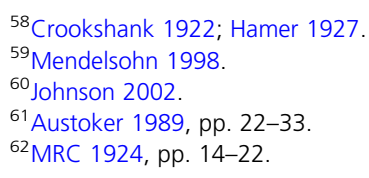

${ }^{58}$ Crookshank 1922; Hamer 1927.

${ }^{59}$ Mendelsohn 1998

${ }^{61}$ Austoker 1989, pp. 22-33

${ }^{62}$ MRC 1924, pp. 14-22. 
war confirmed its importance, Fletcher attributed the failure to control the pandemic to a general lack of institutional support for basic pathological research. He feared that peace time would mark a return to a pre-war pathology, defined by its subordination to clinical and public health interests. ${ }^{63}$ In his first annual report after the war, he characterised British pathology as an anathema to experimental science. ${ }^{64}$ Unlike physiology, which had generated researchers, discoveries, and university departments of international importance, pathology lacked an experimental orientation and a place in universities. In hospitals, medical schools, and public health, its practitioners played a service role, generating income but little new research and few trained researchers. ${ }^{65}$

For Fletcher, the pandemic underscored the need for an experimental approach to pathology located in dedicated laboratories, funded by the state, and coordinated by experts. ${ }^{66}$ This vision found support in the new British Journal of Experimental Pathology. Established in 1920 by a group of MRC researchers, led by Fildes, the journal emphasized the multidisciplinary nature of experimental pathology and its role as a foundation for rational medical knowledge and practice. ${ }^{67}$ The BJEP defined itself as providing an alternative to descriptive research in the morbid anatomy and epidemiology of infectious disease. It aimed to publish 'original communications describing the techniques and results of experimental research into the causation, diagnosis and cure of disease in man' ${ }^{68}$ No one discipline defined this approach. For its founders, experimental pathology joined together 'bacteriological, biochemical, pharmacological, physiological, serological and other subjects' in the production of new pathological knowledge. ${ }^{69}$ Multidisciplinary in character, it was bound together by the core principle of specific aetiology.

Fletcher built this broader vision into his campaign to create new pathology departments at Oxford and Cambridge. ${ }^{70}$ But it was at the NIMR that it was most completely realised. The idea of the Institute was born with the creation of the MRC in 1913. Only after the war was its position consolidated as the flagship for medical science. Occupying Mount Vernon Hospital in Hampstead in North London, built between 1880 and 1900 and purchased by the MRC in 1914, originally it was to be modelled on the Rockefeller Institute for Medical Research in New York (RIMR) (Figure 4). The MRC incorporated important aspects of the Rockefeller approach-particularly the positioning of experimental sciences as foundational to medical education and to the production of medical knowledge and therapeutics-and depended on its patronage. ${ }^{71}$ Yet the MRC research system was also adapted to the British context, where clinical medicine remained dominant. As in Germany, the MRC made the state an active agent of change and used its own authority and institutions to pursue its agendas.

The NIMR was crucial to the MRC mission. An independent government institution, with no formal affiliation with hospitals, its primary function was to foster experimental medicine, with experimental pathology one of its cornerstones. ${ }^{72}$ Experimental pathology

\footnotetext{
${ }^{63}$ Lawrence 2006, p. 48.

${ }^{64}$ MRC 1921, pp. 1-12.

${ }^{65}$ Kohler 1985, pp. 55-6.

${ }^{66}$ Alter 1987.

${ }^{67}$ The first editorial board included Fildes, Mclntosh, J. A. Murray and W. E. Gye.

${ }^{68}$ Fildes 1920, p. i.
}

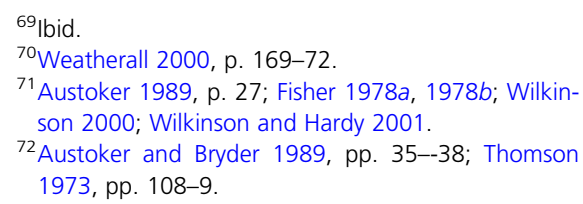




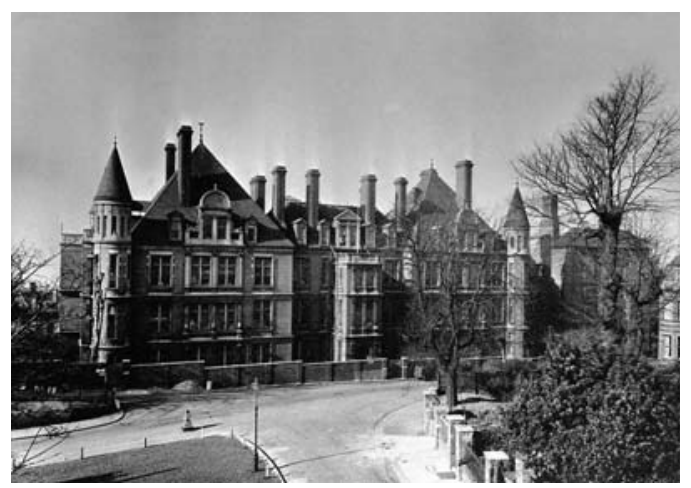

Fig. 4 National Institute for Medical Research—Hampstead (Front View).

Source: Wellcome Library.

came under the remit of the Department of Bacteriology, headed by S. R. Douglas. It shared the Institute's broader organisational ideology of team work, which prioritised research that straddled disciplinary boundaries. ${ }^{73}$ Douglas and Henry Hallet Dale, the Institute's acting director, decided that experimental pathology would be primarily constructed around filterable viruses.

The need for a dedicated virus scheme became readily apparent in the first years after the pandemic, when fresh investigations into the identity of the filter-passer in influenza highlighted the underdeveloped state of the field. In 1920, the MRC started funding new influenza 'virus' work by Mervyn H. Gordon at St Barts Department of Pathology. An enthusiastic researcher, Gordon had worked in the Department since 1908. Early on, he was drawn to testing the idea that filterable agents might be causes of high-profile infectious diseases for which bacterial agents could not be found. In 1912, he confirmed the claim made by the Viennese pathologists Karl Landsteiner and Erwin Popper, that a filter-passer played a primary role in poliomyelitis. ${ }^{74}$ In 1914 , he announced that he had successfully isolated a filter-passer from cases of mumps. ${ }^{75}$ When he returned to filter-passer work after the war, he and Andrewes decided to focus on influenza. A member of the MRC, Andrewes became convinced during the pandemic that a filterable virus held the keys to its aetiology. ${ }^{76}$

An impetus for Gordon's research was a widely reported discovery by two American pathologists, Peter K. Olitsky and Frederick L. Gates, of an alleged 'new' filter-passer from cases of influenza. ${ }^{77}$ Working at the RIMR in New York, Olitsky and Gates first identified the agent during the pandemic. In May 1920 they reported a new technique to produce and serially transmit a 'definite and characteristic' infection in rabbits. Like human influenza, the experimental infection was localized in rabbits' lungs, from where they isolated an agent. To establish its filterability, they passed solutions of ground lung material through grades of Berkefeld filters, and then used the filtrate to reproduce the infection in healthy rabbits. They also employed a special method for

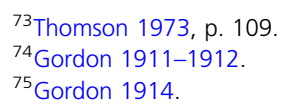

\footnotetext{
${ }^{76}$ Andrewes 1920, pp. 110-15.

${ }^{77}$ Olitsky and Gates 1920.
} 

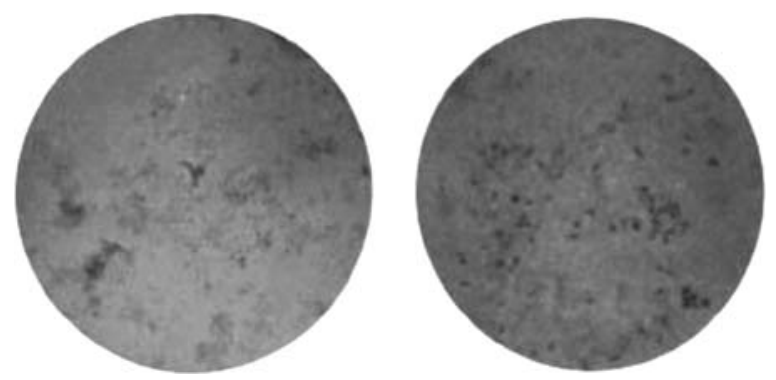

Fig. 5 Olitsky and Gates' Bacterium pneumosintes. Two stained cultures from a rabbit's lung into which were infected nasal secretions from a case of 'epidemic influenza'. On the left, the culture was magnified $\times 1000$. On the right, it was magnified $\times 3000$. Infectivity was tested by inoculation into the lungs of rabbit.

Source: Olitsky and Gates 1921a, p. 729.

cultivating the agent, developed in 1911 by their colleague, the Japanese-born bacteriologist, Hideyo Noguchi. The so-called 'Noguchi' medium was composed of fresh rabbit liver tissue, set in narrow glass tubes, sealed with wax and vaseline. ${ }^{78}$ Rockefeller researchers had used it with the common cold virus, as had British researchers at Etaples in their influenza work. According to Olitsky and Gates, the medium enabled them to make pure cultures of the agent, to photograph it, and to study its properties. In a further fourteen papers published between 1920 and 1923, they detailed its morphological, pathogenic, and serological characteristics. They concluded that it was a minute organism, with particular affinity for the lungs, and accordingly named it, Bacterium pneumosintes -'a bacterium that injures the lung' (Figure 5). ${ }^{79}$

The American researchers's animal model and culture system appeared to solve the two fundamental methodological problems that had hampered filter-passer studies in 1918. Yet, the reception of their research among supporters of the filter-passer theory was mixed. Gordon, for one, believed they had identified an agent similar to that identified by British workers in 1918, and had only 'added precision' to these original studies. ${ }^{80}$ He tested their claims during an epidemic in late December 1921. Using the Noguchi method, he ran bacteriological tests on nasal and throat washings of staff at St Barts Hospital and the Ministry of Health. ${ }^{81}$ In early January he reported to Landsborough Thomson, Assistant Secretary to the MRC, that 'something very like [Olitsky and Gates'] filter passer is coming up in my cultures.' The agent also looked like the one identified by British workers. ${ }^{82}$ But Gordon admitted that, 'rendering the filterable organism was difficult,' because its presence was only indicated by a rather vague 'cloudiness near the piece of kidney at the foot of the [Noguchi] tube.' It became visible when Gordon made films of material that had been fixed, stained, and chemically differentiated. These procedures yielded 'swarms of minute round bodies', but they were so small that they could be 'very easily missed unless especially looked for', and might be dismissed 'by an inexperienced

\footnotetext{
${ }^{78}$ Noguchi 1911.

${ }^{79}$ Olitsky and Gates 1921b, p. 106.

${ }^{80}$ Gordon 1922a, p. 6.
}

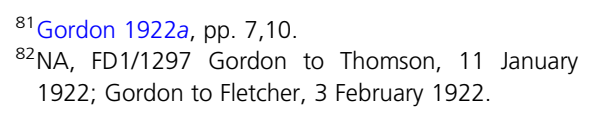




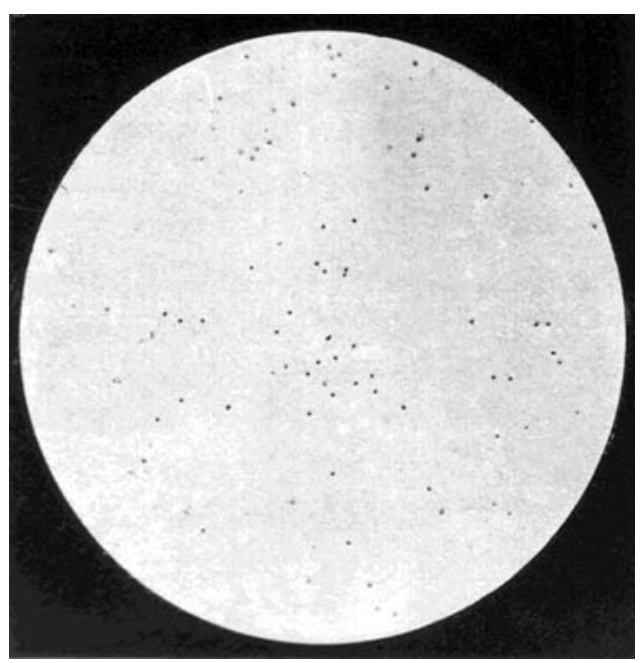

Fig. 6 To Illustrate 'The Filter Passer of Influenza'. Photomicrograph taken for M. H. Gordon by J. E. Barnard at the NIMR in early 1922, of a film of Gordon's filter-passer grown 'in pure culture' in Noguchi medium. Source: Gordon 1922, p. 11.

observer ${ }^{83}$ Unable to induce an experimental disease, Gordon used ultraviolet photomicrographs of the culture and slide preparations to compare their morphology with those described by the British and Americans (Figure 6). It was unclear if the agent was a 'coccoid' or a 'baccilloid', and he was unable to induce disease in experimental animals. Moreover, when he consulted existing literature on filter-passers, he was struck by their similarity with bodies found in other diseases.

These problems raised rather than settled questions about the filter-passer's identity. The most vexing centred on its nature and classification. Gordon and his American counterparts reckoned that it was a filterable organism. Its 'prodigious multiplication' convinced them that it was living and not, as earlier critics had claimed, a protein. ${ }^{84}$ This aligned it with the dominant view of filterable viruses in medical and veterinary pathology: their ability to multiply, demonstrated by pathogenesis, was evidence of their biological nature.

Yet this was not the only theory available for explaining filterable viruses; an important alternative approached them as chemicals. ${ }^{85}$ This theory had various roots, but in British pathology it was most influenced by F. W. Twort's characterization of the bacteriophage as a chemically-induced lytic phenomenon, a concept he introduced in $1915 .{ }^{86}$ H. M. Woodcock, head of the Department of Protozoology at the Lister Institute, enlisted Twort's concept to challenge Gordon. ${ }^{87}$ Woodcock accepted the existence of a pathogenic 'virus', but not that it was living. He argued that those who viewed influenza virus as a microorganism had no direct method for distinguishing it from protein particles. Gordon's microphotographs did not support this conclusion. Quite the contrary, on their staining properties

\footnotetext{
${ }^{83}$ Gordon 1922a, p. 9.

${ }^{84}$ Gordon $1922 b$, p. 400.

${ }^{85}$ Creager 2002, pp. 19, 32-8.
}

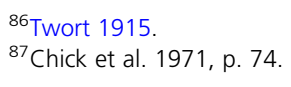


and physical appearance in microphotographs, they looked more like typical 'protein enzymes', the result of the breakdown of cell material by a ferment. ${ }^{88}$ If these bodies were indeed the cause of influenza, Woodcock argued, they were not exogenous organisms but by-products of an endogenous chemical process occurring within human cells.

These debates spilled into a general debate about viruses and virus diseases, and the experimental methods used to elucidate them. Through the early 1920s, the MRC organised several discussions on the state of virus research. The many research challenges were brought to the fore in July 1922 at a special panel on the 'Bacteriology of Influenza' at the annual meeting of the British Medical Association. Concentrating on Gordon's work, discussants probed his filter-passer. James McIntosh recapitulated the view that all studies had failed to establish its pathogenic identity. Sympathetic researchers observed that neither adequate methods nor criteria were available for determining its nature. Charles Ledingham, head of bacteriology at the Lister, argued that the greatest difficulty remained 'the lack of any animal, other than man, [that] was readily susceptible to the causal agent'. Poor filtration methods were identified as yet another obstacle. J. $\mathrm{H}$. Dible, junior lecturer in pathology at Manchester University, noted that filtration was 'extremely crude'; bacterial filters were 'not reliable' and the criteria for deeming an agent 'filterable' depended on an inexact calculation of the relationship between the largest hole in the filter and the smallest bit of protoplasm being filtered; much of the process was left to chance. F. W. Twort stressed the need for standard methods of filtration. W. B. Leishman, who chaired the meeting, concluded that, the status of the filter-passer remained a 'big unsolved problem'. ${ }^{89}$

The BMA meeting made one thing clear: too little was known about the general category of viruses to determine the identity of one. '[The] search for the primary infective agent in influenza,' agreed Gordon, 'has led us into the realm of filter-passers', a realm rife with new problems. ${ }^{90}$ Supporters of the filter-passer theory viewed these problems as features of an emerging field, the boundaries of which urgently needed to be defined. 'For new progress in this field,' noted Fletcher in May 1922, 'every effort must be made to enlist new weapons in the shape of new technical methods of investigation.' ${ }^{91}$

Douglas and Dale were instrumental in positioning the NIMR as the focal point of the MRC virus scheme. The Department of Bacteriology was renamed the Department of Bacteriology and Experimental Pathology, with an emphasis on the latter and priority given to producing basic knowledge of viruses and virus diseases. ${ }^{92}$ In summer 1922 , Dale recruited Patrick Laidlaw to develop the scheme. ${ }^{93}$ A respected Cambridge-trained biochemist and pathologist, Laidlaw had collaborated with Dale at the Wellcome Physiological Laboratories in the early 1900s on studies of the actions of histamine, before being appointed to the William Dunn lectureship in pathology at Guy's in 1913. Preferring the bench to the office desk, he embraced the opportunity. ${ }^{94}$

The NIMR programme was moulded around two lines of work. The first employed physical and biochemical methods to create new instruments and techniques for exploring the

\footnotetext{
${ }^{88}$ Creager 2002, pp. 32-3.

${ }^{89}$ 'Bacteriology of Influenza', Lancet, 1922, pp. 516-18.

${ }^{90}$ Gordon $1922 a$, p. 11.
}

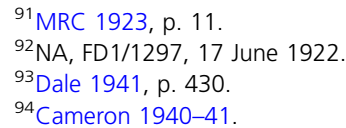

${ }^{91} \mathrm{MRC} 1923$, p. 11.

${ }^{93}$ Dale 1941, p. 430.

${ }^{94}$ Cameron 1940-41 
fundamental nature of viruses. Its main locus was the Department's Division of Applied Optics, created in 1920 for J. E. Barnard, a west-end hatter and amateur microscopist, who built the first ultra-violet microscope in Britain. ${ }^{95}$ Bernard worked with William Gye on the role of a filterable virus in cancer sarcomas, and explored physical problems associated with rendering viruses visible and with filtration methods for purifying and determining their size. ${ }^{96}$ The second line of work concentrated on creating pathological and 'immunological devices' for the investigation, identification and control of virus diseases. ${ }^{97}$ Familiar to bacteriologists, these techniques included new media and experimental animals for growing viruses, and serological assays, therapeutic sera, and vaccines for typing and controlling them. Both research lines were closely entwined. But it was the applied aspects of the programme that linked it to medical and public health concerns with influenza and other disease with unknown aetiologies.

\section{An Influenza Model: Distemper Virus}

The public and medical profile of influenza remained high throughout the 1920s. Prior to the pandemic it had been viewed as an inescapable part of modern life; but after it was viewed as a major threat. ${ }^{98}$ No one knew if, or when, it would again become a deadly pandemic. Influenza typically ranked highest amongst cases reported by general practitioners and amongst patients' complaints. ${ }^{99}$ There was greater awareness of the disease, with 1922, 1924, 1927 and 1929 designated epidemic years. Among infectious diseases, only diphtheria and scarlet fever accounted for higher annual morbidity. ${ }^{100}$ Although influenza rarely killed on its own, 'influenzal pneumonia' accounted for stunning levels of mortality killing on average nearly ten times more people than diphtheria or measles. ${ }^{101}$

Resolving influenza's aetiology remained a paramount problem. The MRC considered including it on the NIMR programme. But it was deemed unsuitable for basic work because of its aetiological complexity and the lack of a viable experimental animal. Rather, it would be studied indirectly through a model disease. When plans were settled in June 1922, three 'virus' diseases were chosen: measles, chicken sarcoma-a model for human cancer-and dog distemper, which served as the model for influenza. According to Fletcher, distemper's apparent analogies made it 'peculiarly suitable for working out methods by which human diseases of this class might be subsequently investigated. ${ }^{102}$

Distemper addressed a broad range of MRC interests. As Fletcher highlighted in his Annual Report for 1921-22, its relevance as a potential model for influenza was most important:

There is good reason to think that [dog distemper] offers a close parallel to human influenza. It seems probable that the infective agent is a filterable virus, and that here also the severity of the resulting disease depends largely upon secondary infections, facilitated by the primary infection. There is ground for hope that the study of dog's distemper under strict experimental conditions may throw important light

\footnotetext{
${ }^{95}$ Austoker and Bryder 1989; Thomson 1973, pp. 112-13.

${ }^{96}$ Austoker 1988, pp. 93-8.

${ }^{97}$ MRC 1930, p. 15.

${ }^{98}$ Honigsbaum 2010; Bresalier 2010, ch. 1.
}

\footnotetext{
${ }^{99}$ Digby 1999, pp. 209, 213.

${ }^{100}$ Deutschman 1953, p. 636.

${ }^{101}$ Ministry of Health 1930, p. 30.

${ }^{102}$ NA, FD1/1297, 3 May 1922
} 
upon analogous problems of human disease, and at least suggest new clues for investigation or new technical methods for the investigator. It is with the primary object of gaining knowledge of human disease that the Council decided to support further study of distemper in dogs. On that ground alone they find complete justification of the expenditure of part of their funds in this direction. ${ }^{103}$

Concerned that the focus on distemper might be seen as being at odds with the NIMR's mandate to work on human diseases, Fletcher framed it as good for exploring influenza and general problems associated with virus infection and immunity. ${ }^{104}$

Important analogies also existed between the state of research on distemper and on influenza. Veterinary pathologists were divided on whether a filterable virus or a bacillus caused distemper. Its virus aetiology had been first proposed in 1905, but then widely disputed by researchers who aligned themselves behind $B$. bronchisepticus, identified in 1911. ${ }^{105}$ Crucially, neither side had access to dogs bred under controlled conditions, so results could always be contested. Without accurate means to isolate and test either agent, there was little hope for a vaccine. ${ }^{106}$

The prospect of resolving these problems drew together British virus researchers, veterinarians and dog owners. In late 1922, as the NIMR was assembling its programme, the country magazine, The Field, and the Veterinary Journal launched a Dog Distemper Fund, with the aim of raising $\mathrm{f25,000}$ for new research. ${ }^{107}$ In early 1923, Sir Theodore Cook, The Field's editor and Honorary Secretary of the Fund approached Fletcher about collaborating on 'research into the causation, prevention, and treatment of distemper'. ${ }^{108}$ While a government body, funded through the National Health Insurance system, the MRC actively sought out patrons for its schemes. Its close collaborations with wealthy benefactors, the Rockefeller Foundation and Dunn Trust, are well known. ${ }^{109}$ But its collaboration with the Distemper Fund involved a different form of patronage, one that depended on a large and varied group rather than a mighty patron. The Fund relied on voluntary contributions from hunt packs, kennels, breeders, associations and middle class dog owners from across Britain and the Empire, and from the United States. Support went well beyond monetary contributions, as many made their own dogs available as research subjects.

Managing these different interests required a novel research organisation. A Distemper Research Council was created to oversee fund-raising and publicity, and an expert Distemper Research Committee was created to coordinate scientific work at the NIMR. ${ }^{110}$ All participants shared the belief that experimental research was the best way to develop effective control technologies against distemper. The NIMR's Department of Bacteriology and Experimental Pathology was made the fulcrum and Laidlaw made dog distemper his main research object.

\footnotetext{
${ }^{103}$ MRC 1923, pp. 12-13.

${ }^{104}$ MRC 1923, p. 13; NA, FD1/1275 Fletcher to C.J. Martin, 13 October 1922.

${ }^{105}$ Laidlaw and Dunkin 1926, pp. 222-3; Laidlaw and Dunkin 1928a, pp. 5-6.

${ }^{106}$ Laidlaw and Dunkin 1928a, pp. 5-6.

${ }^{107}$ Worth nearly $f 750,000.00$ in 2005 . The Fund eventually raised over $£ 38,000$ ( $₫ 1,270,000)$. For details,
}

see NA, FD1/1279, 'Saving the Living of our Dogs', The Field, 4 February 1933, pp. i-xiii.

${ }^{108}$ MRC 1924, p. 85.

${ }^{109}$ Kohler 1978; Lawrence 2006.

${ }^{110} \mathrm{NA}, \mathrm{FD} 1 / 1275$, The Cure and Causes of Distemper, November 1924. 
Between 1923 and 1932 Laidlaw worked with the resident veterinary pathologist, G. W. Dunkin, on all aspects of the disease. The single most important obstacle was access to purpose-bred dogs. The need for controlled supplies of experimental animals was a general problem for the Institute. ${ }^{111}$ With the support of the Fund, the MRC built a large-scale, animal-breeding and research facility at Mill Hill, an agricultural site north of Hampstead. ${ }^{112}$ Completed in 1924, the 'Farm Laboratories' made provision for breeding and housing dogs and other large animals, a well-equipped laboratory, and an isolation compound for quarantining distempered dogs. ${ }^{113}$

The facility put Laidlaw and Dunkin in a unique position to carry out distemper studies under controlled conditions and to settle the dispute over the causative agent. By 1926, they had ruled out $B$. bronchisepticus and had established a strong foundation for a filterable virus. ${ }^{114}$ The telling piece of evidence came when they used bacteria-free filtrates to reproduce an experimental infection in their dogs. ${ }^{115}$ This enabled them to determine the pathogenesis and role of the agent. Its filterability partially confirmed its identity, but equally important was its resistance to cultivation. The result was in line with the emerging view that failure to grow filterable viruses in artificial culture was evidence of their unique dependence on living tissue. ${ }^{116}$ While the nature of this dependence was not well understood, it was increasingly taken as a defining property. Laidlaw and Dunkin could thus legitimately claim that, 'from these three [factors] it follows that the infecting agent of dog-distemper belongs to the class of filter-passing viruses. ${ }^{117}$

Once they settled the aetiology, they turned their attention to a vaccine. But dogs were not ideal for tackling the problem. Dog experimentation was the target of vociferous antivivisection campaigns. ${ }^{118}$ Moreover, the animals were ill-suited for the work. ${ }^{119}$ In particular, distemper varied considerably in dogs, making it difficult to diagnose. Searching for a solution, Laidlaw and Dunkin found that the ferret was highly susceptible to distemper, and easily reproduced and identified in the animal. ${ }^{120}$ Ferrets were also easier to manage. They bred readily and quickly. Unlike the dog, they were known to thrive in small spaces, which made them well suited to confinement in laboratory cages. ${ }^{121}$ They were ideal research animals.

By 1927, Laidlaw and Dunkin developed and tested experimental vaccines for ferrets and dogs. ${ }^{122}$ Their key innovation was a two-step immunisation process. It involved first administering a killed virus, waiting 7-14 days until the animal developed sufficient antibodies, and then injecting it with live virus. ${ }^{123}$ Following successful trials, in 1928 the Distemper Council arranged for its commercial production by Burroughs Wellcome \& Co in Britain and two American companies in the United States. ${ }^{124}$ The vaccine became widely available in 1931.

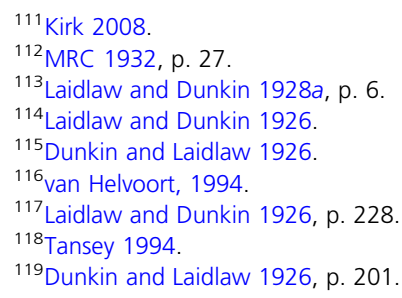

${ }^{120} \mathrm{NA}$, FD1/1275 Third Report of the Distemper Research Committee-'Ferrets', 7 October 1924, Thomson 1951, pp. 471-80.

${ }^{121}$ Laidlaw 1930, pp. 232-43.

${ }^{122}$ Laidlaw and Dunkin 1927, pp. 1-16.

${ }^{123}$ Laidlaw and Dunkin 1927, pp. 9-10; 1928b, p. 3; 1928a, pp. 13-15; 1928b, pp. 215-26.

${ }^{124}$ Laidlaw and Dunkin 1928a, p. 11. The American houses were Lederle Laboratories, in New York, and Murphy Laboratories in Philadelphia. 
The distemper campaign was hailed as an enormous success. Dale described it as an exemplar of 'a complete and systematic investigation of a virus disease', and its culmination of a vaccine for the nation's dog owners made it symbolise the efficacy of the NIMR's approach to virus research. ${ }^{125}$ A number of aspects ensured that it had wide-reaching significance. It established a style of virus research that linked together fundamental and applied research in ways that broke down that distinction. The innovation and commercial manufacture of a vaccine demonstrated the practical relevance of virus research. From a professional standpoint, the campaign was crucial to legitimising virus research. When Laidlaw and his colleagues started their work in 1923, the challenges of rendering viruses by established bacteriological techniques of filtration, in vitro cultivation and light microscopy were well known. Not only did these challenges spur technical innovations, they also gave rise to new ways of thinking, the most important of which was the concept of viruses as obligate parasites - entities dependent on living tissue for their multiplication. While this concept had been proposed as early as 1900, as researchers ran up against limitations of culture techniques in the 1920s, it grew into a basic framework. Investigating viruses in experimental animals became a necessary condition of medical and veterinary virus research. Work at the NIMR became organised around this biological concept of viruses and the experimental approach it demanded. The distemper campaign proved that the approach was immensely productive of both expert knowledge and practical tools for tackling virus diseases.

When Laidlaw and Dunkin handed over responsibility for their distemper vaccine to Burroughs Wellcome in 1931, virus research was becoming an established medical scientific field. Through distemper, NIMR workers fashioned their scientific identities as virus researchers and the authority of their Institute. Laidlaw was knighted for his distemper work in 1933. Virus research was funded in universities and hospitals, and the Lister had created its own programme. In 1929, the MRC devoted an entire volume of its System of Bacteriology in Relation to Medicine to 'Viruses and Virus Diseases', and dog distemper occupied a key place in the category. ${ }^{126}$

The MRC had always justified distemper research in terms of its potential applications to influenza. Fletcher returned to the theme in 1931, writing that,

It is already clear that the usefulness of this work is not to be limited to the prevention and cure of canine distemper. In the field of medical research the work has at many points aided the development of technical methods for the study of viruses in general. $^{127}$

By the end of the campaign, the MRC had rallied much support for its convinction that virus research could conquer influenza.

\section{Viralizing Influenza}

Through the 1920s, medical and public concern about influenza's toll grew. A Times editorial in 1928 observed that,

\footnotetext{
${ }^{125}$ Cameron $1940-41$, p. 9.

${ }^{126}$ Fildes and Ledingham 1930.
} 
At more or less regular intervals, influenza breaks out and marches across the world, claiming millions of victims and causing grievous dislocation of human enterprise. Immense sums of money are spent on sickness benefits and on the care of the sick, and heavy losses are incurred by the majority of industrial undertakings; while numberless men and women lose their health permanently and become dependent on others. ${ }^{128}$

The following year, the same paper bemoaned '[T]he sad state of unpreparedness in which the world finds itself ought to awaken determination to discover, if possible, some means of prevention. ${ }^{\prime 129}$ Yet, hope was at hand. The editorial went on to note that an effective approach had been demonstrated with dog distemper:

Is it too much to ask that work on similar lines be undertaken on the cause of influenza? The work on distemper has opened a way; general studies organized by the Medical Research Council on virus diseases have made parts, at any rate, of that way smooth. Has not the time arrived to launch a campaign and to come to grips with the enemy? ${ }^{130}$

These comments suggest that the MRC's strategy of linking influenza to distemper research had been successful in redefining the disease as a problem for virus research. Fletcher's rhetoric, now echoed in The Times and other general press, raised expectations that tools created to control distemper could be applied to influenza. In early 1932, Sir Halley Stewart, an important MRC patron, offered Fletcher $£ 2,500$ to launch an 'Influenza Campaign'. ${ }^{131}$

Linkage to the distemper campaign was both symbolic and pragmatic. The campaign's success legitimised the NIMR approach to virus diseases. Its primary goal had become virus identification and control through the production of serological assays, therapeutic sera and, ultimately, vaccines. New interest in applying this approach to influenza was ignited in 1931, when the American veterinary pathologist, Richard E. Shope announced that a combination of Haemophilus bacillus (suis) and a filterable virus produced a disease in pigs_-'hog flu' - that was analogous to human influenza. ${ }^{132}$ Shope's work prompted speculation that a similar type of infection might be the cause of human influenza and re-opened the possibility of finding an animal model for the disease.

In late 1932, the MRC decided to concentrate its influenza efforts at the NIMR, under the control of Laidlaw. ${ }^{133}$ Within months, the decision paid off. In early 1933, Laidlaw and two young researchers, C. H. Andrewes and Wilson Smith, succeeded in using the ferret to isolate a filter-passer from patients in London, including Smith himself, and they rapidly identified the agent they called 'W.S.' virus as the primary cause. While Shope's work provided an incentive for the research, its organisation, material foundations, personnel and general reception were directly shaped by the distemper campaign. By end of the 1930s,

${ }^{128}$ The Times, 28 December 1928, p.13.

${ }^{129}$ The Times, 29 December 1932, p. 9.

${ }^{130}$ Ibid.

${ }^{131}$ NA, FD1/3356 Influenza, Halley Stewart to Fletcher, 2 January 1933. $f 2,500$ was roughly equivalent to $\mathrm{f} 90,000.00$ in 2005.

\footnotetext{
${ }^{132}$ Shope 1931.

${ }^{133}$ I have traced this story in Bresalier 2008, 2010. Also see, Eyler 2006.
} 
influenza's virus identity had become part of medical and public health knowledge, and the NIMR collaborated with researchers around world in developing diagnostic techniques and vaccines. The NIMR's success came so quickly only because so much had been put in place in the previous decade.

\section{Conclusion}

Influenza's virus identity is now taken for granted. I have shown that the link between the virus and the disease has many histories. Its genesis needs to be traced not to its 'discovery' in 1933 but to the battlefields of the First World War, to military pathology, and to debates over influenza's aetiology during and after the 1918-19 pandemic. Most crucial to this process was the strategic use of the pandemic by the MRC to justify construction of virus research, which created the material conditions for Laidlaw and his team to establish influenza as a virus disease.

Historians of virology conventionally suggest that medical and veterinary virus work of the kind pursued at the NIMR was bound to a 'bacteriological paradigm', which acted as an obstacle to the development of a modern biochemical virus concept. ${ }^{134}$ My account challenges this view. Contrary to the notion that NIMR virus research was defined by bacteriology, I have shown that viruses and virus diseases were construed as complex research problems requiring a multidisciplinary and collaborative approach. Virus workers were committed to the principle of specific aetiology and bacteriology provided an ontological understanding of viruses and methods for tackling them. But the NIMR framed virus work as a form of 'experimental pathology', and NIMR reseachers, and their colleagues, identified themselves as 'experimental pathologists' rather than as bacteriologists. This distinction took on important meaning as it became evident that viruses resisted bacteriological methods. Work done at the NIMR, and elsewhere through the 1920s, slowly yielded a concept of viruses as obligate parasites, which set viruses apart from bacteria and forced workers to develop specific skills and knowledge, and new scientific identities. ${ }^{135}$ My account of the NIMR programme supports Angela Creager's observation that, rather than being bound by one disciplinary framework, interwar virus work is better understood in terms of its dependence on the interchange of bacteriological, pathological, physical and biological practices. ${ }^{136}$ As the distemper case shows, this collaborative enterprise extended beyond the laboratory walls, involving relations with other professionals and lay constituencies.

The MRC's ability to rally different groups to the cause of virus research was tied to how it mobilised the experience of the 1918-19 pandemic. My analysis challenges the standard historiographical view that the pandemic had little lasting impact on medical or social institutions. ${ }^{137}$ The MRC's virus scheme shows that the pandemic played key roles in the creation of a research system that became an emblem of scientific modernity. Rather than leading to the abandonment of laboratory-based pathology, failure to master the pandemic spurred the MRC to improve and expand it. The MRC's ability to mobilize the pandemic points to the existence of a broad consensus about the threat of influenza.

\footnotetext{
${ }^{134}$ van Helvoort 1993, 1994.

${ }^{135}$ Laidlaw 1938; Rivers 1928.
}

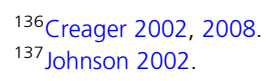


The story told here suggests we rethink how we write the history of the pandemic. Rather than use virology as an explanatory resource, we need to examine its construction as a multidisciplinary field and how influenza-and other diseases-figured into this process. My analysis of the MRC's virus programme underscores the need for accounts of how different actors and institutions used the pandemic to pursue different agendas. Historians have acknowledged government support for the MRC during the pandemic but not how the MRC subsequently mobilised the experience in its post-war plans. In this context, virus research emerged as a new domain for tackling infectious diseases and a vehicle for constructing a new experimental pathology. Ignoring this dimension of virus research means we ignore its crucial role in shaping the history and meanings of the pandemic.

\section{Acknowledgements}

Many thanks to Michael Worboys, Carsten Timmerman, John Pickstone and colleagues at CHSTM for valuable comments and suggestions.

\section{Bibliography Primary sources}

National Archives, Kew, Surrey.

\section{Secondary sources}

Abrahams A. et al. 1919, 'A Further Investigation into Influenzo-pneumococcal and Influenzo-streptococcal Septicaemia: Epidemic Influenzal "Pneumonia" of Highly Fatal Type and its Relation to "Purulent Bronchitis"', Lancet, 4 January, 1 -11.

Alter P. 1987, The Reluctant Patron: Science and the State in Britain 1850-1920, Oxford: Berg.

Andrewes F. W. 1920, 'The Bacteriology of Influenza', in Ministry of Health, Report on the Pandemic of Influenza, 1918-19, London: HMSO, 110-25.

Arkwright J. A. 1919, 'A Criticism of Certain Recent Claims to Have Discovered and Cultivated the Filter-passing Virus of Trench fever and of Influenza', British Medical Journal, 23 August, 233-5.

Austoker J. 1988, A History of the Imperial Cancer Research Fund, 1902-1986, Oxford: Oxford University Press.

Austoker J. 1989, 'Walter Morley Fletcher and the Origins of a Basic Biomedical Research Policy', in Austoker J. and Bryder L. (eds), Historical Perspectives on the Role of the MRC: Essays in the History of the MRC of the United Kingdom and its Predecessor, the Medical Research Committee, 1913-1953, Oxford: Oxford University Press, 22-33.

Austoker J. and Bryder L. 1989, 'The National Institute for Medical Research and Related Activities of the MRC', in Austoker J. and Bryder L. (eds), Historical Perspectives on the Role of the MRC: Essays in the History of the MRC of the United Kingdom and its Predecessor, the Medical Research Committee, 1913-1953, Oxford: Oxford University Press, 39-52.

Bradford J. R., Bashford E. F. and Wilson J. A. 1919a, 'Preliminary Report on the Presence of a FilterPassing Virus in Certain Diseases with special reference to Trench Fever, Influenza and Nephritis', Lancet, 1 February, 169.

Bradford J. R., Bashford E. F. and Wilson J. A. 1919b, 'The Filter-passing Virus of Influenza', Quarterly Journal of Medicine, 12, 259-306.

Bresalier M. 2008, 'Neutralizing flu: "Immunological Devices" and the Making of a Virus Disease', in Kroker K, Keelan J. and Mazumdar P. M. H. (eds), Crafting Immunity: Working Histories of Clinical Immunology, Basingstoke: Ashgate, 107-44.

Bresalier M. 2010, 'Transforming Flu: Medical Science and the Making of a Virus Disease in London, 1890-1939', PhD Dissertation, University of Cambridge. 
Bresalier M. 2011, 'Fighting Flu: Military Pathology, Vaccines, and the Conflicted Identity of the 1918-19 Pandemic in Britain', Journal of the History of Medicine and the Allied Sciences, September 11 [Epub ahead of print] doi:10.1093/jhmas/jr041.

Brown R. J. 2003, 'The Great War and the Great Flu pandemic of 1918', Wellcome History, 24, 5-7.

Burnet F. M. and Clark E. 1942, Influenza: A Survey of the Last 50 Years in the Light of Modern Work on Virus of Epidemic Influenza, Melbourne: Macmillan.

Byerly C. R. 2005, Fever of War: The Influenza Epidemic in the U.S. Army during World War I, New York: New York University Press.

Cameron H. C. 1940-41, 'Patrick Playfair Laidlaw', Guy's Hospital Reports, 90, 1-14.

Coles A. C. 1904, Clinical Diagnostic Bacteriology, London: J\&A Churchill.

Cooter R. 2003, 'Of War and Epidemics: Unnatural Couplings, Problematic Conceptions', Social History of Medicine 16, 283-302.

Creager A. N. H. 2002, The Life of a Virus: Tobacco Moasaic Virus as an Experimental Model, 1930-65, Chicago: University of Chicago Press.

Creager A. N. H. 2008, 'Mobilizing Biomedicine: Virus Research Between Lay Health Organizations and the U.S. Federal Government, 1935-1955', in Hannaway C. (ed.), Biomedicine in the Twentieth Century: Practices, Policies, and Politics, Amsterdam: IOS Press, 171-202.

Crookshank F. G. 1922, Influenza: Essays by Several Authors, London: Heinemann.

Crosby A.W. 1989, America's Forgotten Pandemic-The Influenza of 1918, Cambridge: Cambridge University Press.

Cummins S. L. 1919a, 'Major H.G. Gibson', British Medical Journal, 8 March, 294-5.

Cummins S. L. 1919b, Studies of Influenza in Hospitals of the British Armies in France, MRC, Special Report Series No. 36 London: HMSO.

Dale H. H. 1941, 'Patrick Playfair Laidlaw', Obituary Notices of Fellows of The Royal Society, 3, 427-47.

Deutschman Z. 1953, 'Trends of Influenza Mortality During the Period 1920-1951', Bulletin of the World Health Organization, 8, 633-45.

Digby A. 1999, The Evolution of British General Practice, 1850-1948, Oxford: Oxford University Press.

Donaldson R. 1922, 'The Bacteriology of Influenza-With Special Reference to Pfeiffer's Bacillus', in Crookshank F. G. (ed.), Influenza: Essays by Several Authors, London: William Heinemann, 139-213.

Dunkin G. W. and Laidlaw P. P. 1926, 'Studies in Dog-Distemper. II. Experimental Distemper in the Dog', Journal of Comparative Pathology and Therapeutics, 39, 201-13.

Editorial 1918, 'The Utilisation of Vaccine for the Prevention and Treatment of Influenza', Lancet, 26 October, 565.

Editorial 1922, 'Bacteriology of Influenza', Lancet, ii, 516-18.

Eyler J. M. 2006, 'De Kruif's Boast: Vaccine Trials and the Construction of a Virus', Bulletin of the History of Medicine, 80, 409-38.

Fildes P. 1920, 'Unititled Editorial', British Journal of Experimental Pathology, 1, i-ii.

Fildes P. and McIntosh J. 1920, 'The Aetiology of Influenza', British Journal of Experimental Pathology, 2, 159-174.

Fildes P. 1949, 'James McIntosh 1882-1948', Journal of Pathology and Bacteriology, 61, 285-99.

Fildes P. and Ledingham J. C. G. 1930, 'Viruses and Virus Diseases', in Fildes P. et al., (eds), A System of Bacteriology in Relation to Medicine, London: HMSO.

Fildes P. and McIntosh J. 1920, 'The Aetiology of Influenza', British Journal of Experimental Pathology, II, 159-74.

Fisher D. 1978a, 'The Rockefeller Foundation and the Development of Scientific Medicine in Britain', Minerva, 16, 20-41.

Fisher D. 1978b, 'Rockefeller Philanthropy and the British Empire: The Creation of the London School of Hygiene and Tropical Medicine', History of Education, 7, 129-43.

French H. 1919, 'Influenza, Guy's Hospital Gazette, XXXIII, 118-27.

Garrod L. P. 1954, 'Mervyn H. Gordon 1872-1953', Obituary Notices of Fellows of the Royal Society, 9, 153-63. 
Gibson H. G., Bowman F. B. and Connor J. I. 1918, 'A Filtrable Virus as the Cause of the Early Stage of the Present Epidemic of Influenza', British Medical Journal, 14 December, 645-6.

Gibson H. G., Bowman F. B. and Connor J. I. 1919, 'The Etiology of Influenza: A Filterable Virus as the Cause', in MRC Studies of Influenza in Hospitals of the British Armies in France, 1918, London: HMSO, 19-36.

Gladstone G. P., Knight C. J. G. and Wilson G. 1973, 'Paul Gordon Fildes, 1882-1971', Biographical Memoirs of Fellows of the Royal Society, 19, 317-74.

Gordon M. H. 1911-1912, 'Notes on Acute Poliomyelitis with Reference to its Etiology, Histology, and Immunity', Reports of Local Government Board, Medical Officer, London: HMSO, 115-21.

Gordon M. H. 1914, 'On Experimental Investigations in Relation to Mumps or Epidemic Parotitis,' Reports of Local Government Board, Public Health, 96, London: HMSO.

Gordon M. H. 1922a, 'The Filter Passer of Influenza', Journal of the Royal Army Medical Corps, 39, $1-12$.

Gordon M. H. 1922b, 'The Filter Passer of Influenza', Journal of the Royal Army Medical Corps, 39, 400-01.

Hamer W. H. 1927, 'The Influenzal Constitution', Proceedings of the Royal Society of Medicine, 20, 1349-68.

Honigsbaum M. 2010, 'The Great Dread: Cultural and Psychological Impacts and Responses to the "Russian" Influenza in the United Kingdom, 1889-1893', Social History of Medicine 23, 299-319.

Horder T. S. 1918, 'Influenza and Preventive Inoculation', Lancet, 9 November, 642.

Influenza Committee of the Advisory Board to the D.G.A.M.S. 1918, 'The Influenza Epidemic in British Armies in France, 1918', British Medical Journal, 9 November, 50.

Johnson N. P. A. S. 2002, 'The Overshadowed Killer: Influenza in Britain in 1918-19', in Phillips H. and Killingray D. (eds), The Spanish Influenza of 1918-1919: New Perspectives, London: Routledge, 132-54.

Johnson N. P. A. S. and Mueller J. 2002, 'Updating the Accounts: Global Mortality of the 1918-1920 "Spanish" Influenza Epidemic', Bulletin of the History of Medicine, 76, 105-15.

Kirk R. G. W. 2008, '“Wanted-Standard Guinea Pigs": Standardisation and the Experimental Animal Market in Britain ca. 1919-1947', Studies in History and Philosophy of Biological and Biomedical Sciences, 39, 280-91.

Kitasato S. 1892, 'On the Influenza Bacillus and the Mode of Cultivating It', British Medical Journal, 16 January, 128.

Klein E. 1892, 'Some Remarks on the Influenza Bacillus', British Medical Journal, 23 January, 171.

Klein E. 1893, 'Report on Influenza in its Clinical and Pathological Aspects', Local Government Board, Further Report and Papers on Epidemic Influenza, 1889-92 London: HMSO, 85-153.

Kohler R. E. 1978, 'Walter Fletcher, F.G. Hopkins, and the Dunn Institute of Biochemistry: A Case Study in the Patronage of Science', Isis, 69, 331-55.

Kohler R. E. 1985, 'Bacterial Physiology: The Medical Context', Bulletin of the History of Medicine, 59, 54-74.

Kruse W. 1914, 'Die Erreger v. Husten und Schnupfen', Münchener medizinische Wochenschrift, 65, 1228.

Laidlaw P. P. 1930, 'Dog Distemper', in Fildes P. and Ledingham J. C. G. (eds), A System of Bacteriology, London: HMSO.

Laidlaw P. P. 1938, Virus Diseases and Viruses, Cambridge: Cambridge University Press.

Laidlaw P. P. and Dunkin G. W. 1926, 'Studies in Dog-Distemper. III. The Nature of the Virus', Journal of Comparative Pathology and Therapeutics, 29, 222.

Laidlaw P. P. and Dunkin G. W. 1927, 'Studies in Dog Distemper. IV. The Immunization of Ferrets against Dog Distemper', Journal of Comparative Pathology and Therapeutics, 41, 1-16.

Laidlaw P. P. and Dunkin G. W. 1928a, A Report Upon the Cause and Prevention of Dog Distemper, Distemper Research Committee.

Laidlaw P. P. and Dunkin G. W. 1928b, 'Studies in Dog Distemper. V. The Immunization of Dogs', Journal of Comparative Pathology and Therapeutics, 41, 209-27.

Langford C. 2002, 'The Age Pattern of Mortality in the 1918-19 Influenza Pandemic: An Attempted Explanation Based on Data for England and Wales', Medical History, 46, 1-20. 
Lawrence C. 2006, Rockefeller Money, the Laboratory, and Medicine in Edinburgh, 1919-1930: New Science in an Old Country, Rochester: University of Rochester Press.

Leishman W. B. 1923, 'Organization of the Pathological Service', in MacPherson W. G., Leishman W. B. and Cummins S. L. (eds), History of the Great War Based on Official Documents. Medical Services. Pathology. London: HMSO, 1-31.

McIntosh J. 1918, 'The Incidence of Bacillis Influenzae (Pfeiffer) in the Present Influenza Epidemic', Lancet, 23 November, 695-7.

McIntosh J. 1922, Studies in the Aetiology of Epidemic Influenza, MRC Special Report Series, no. 63, London: HMSO.

Maitland H. B. and Cameron G. C. 1921, 'The Aetiology of Epidemic Influenza: A Critical Review', Canadian Medical Association Journal, XI, 485-92.

Maitland H. B. et al. 1921, The Aetiology of Epidemic Influenza: Experiments in Search of a Filterpassing Virus. Toronto: The University Library.

Matthews J. 1918, 'Influenza and Preventive Inoculation', Lancet, 2 November, 602.

MRC 1919, Studies of Influenza in Hospitals of the British Armies in France, 1918, London: HMSO.

MRC 1921, Report of the Medical Research Council for the Year 1919-1920, London: HMSO.

MRC 1923, Report of the Medical Research Council for the Year 1921-1922, London: HMSO.

MRC 1924, Report of the Medical Research Council for the Year 1922-1923, London: HMSO.

MRC 1927, Report of the Medical Research Council for the Year 1925-1926, London: HMSO.

MRC 1930, Report of the Medical Research Council for the Year 1928-1929, London: HMSO.

MRC 1932, Report of the Medical Research Council for the Year 1930-1931, London: HMSO.

MRC 1933, Report of the Medical Research Council for the Year 1931-1932, London: HMSO.

Mendelsohn J. A. 1998, 'From Eradication to Equilbrium: How Epidemics Became Complex after

World War I', in Lawrence C. and Weisz G. (eds), Greater than the Parts: Holism in Biomedicine,

1921-1950, Oxford: Oxford University Press, 303-31.

Ministry of Health 1920, Report on the Pandemic of Influenza, 1918-19, London: HMSO.

Ministry of Health 1927, Memorandum on Influenza (rev. edn), London: HMSO.

Ministry of Health 1930, Eleventh Annual Report, 1929-1930, London: HMSO.

Morens D. M. and Taubenberger J. K. 2009, 'Understanding Influenza Backwards', Journal of the American Medical Association, 302, 679-80.

Newsholme A. 1918-1919, 'Discussion on Influenza', Proceedings of the Royal Society of Medicine, 12, 1-102.

Noguchi H. 1911, 'A Method for the Pure Cultivation of Pathogenic Treponema pallidum (Spirochata Pallida)', Journal of Experimental Medicine, 14, 99-108.

Olitsky P. and Gates F. L. 1920, 'Experimental Study of the Nasopharyngeal Secretions from Influenza Patients: Preliminary Report', Journal of the American Medical Association, 74, 1497-9.

Olitsky P. and Gates F. L. 1921a, 'Experimental Studies of Nasopharyngeal Secretions from Influenza Patients: IV. Anaerobic Cultivation', Journal of Experimental Medicine, 33, 713-29.

Olitsky P. and Gates F. L. 1921b, 'Studies of the Nasopharyngeal Secretions from Influenza Patients: Preliminary Report on Cultivation Experiments', Journal of the American Medical Association, 76, 640-1.

Olitsky P. and Gates F. L. 1922, 'Methods for the Isolation of Filter-passing Anaerobic Organisms: From Nasopharyngeal Secretions', Journal of the American Medical Association, 78, 1020-2.

Oxford J. S. 2001, 'The So-called Great Spanish Influenza Pandemic of 1918 May Have Originated in France in 1916', Philosophical Transactions of the Royal Society of London, B, 336, 1857-9.

Pfeiffer R. 1892, 'Preliminary Communication on the Exciting Causes of Influenza', British Medical Journal, 16 January, 128.

Pfeiffer R. 1893, 'Die Aetiologie der Influenza', Zeitschrift für Hygiene, 12, 357-86.

Pfeiffer R. and Beck M. 1892, 'Weitere Mittheilungen über den Influenza-Erreger', Deutsche Medicinische Wochnenschrift, 18, 465.

Prüll C. -R. 1998, 'Pathology and Surgery in London and Berlin 1800-1930: Pathological Theory and Clinical Practice,' in Prüll C. R. (ed.), Pathology in the 19th and 20th Centures: The Relationship between Theory and Practice, Sheffield: European Association for the History of Medicine and Health Publications, 71-100. 
Prüll C.-R. 1999, 'Pathology at War 1914-1918: Germany and Britain in Comparison', in Cooter R., Harrison M. and Sturdy S. (eds), Medicine and Modern Warfare, Amsterdam: Rodopi, 131-62.

Rivers T. M. 1928, 'Some General Aspects of Filterable Viruses', in Rivers T. M. (ed.), Filterable viruses, London: Bailliere, Tindall \& Cox, 3-52.

Shope R. E. 1931, 'Swine Influenza. III. Filtration Experiments and Etiology', Journal of Experimental Medicine, 54, 373-85.

Smith W., Andrewes C. H. and Laidlaw P. P. 1933, 'A Virus Obtained from Influenza Patients', Lancet, 8 July, 66-68.

Soltau A. B. 1919, 'Discussion on Influenza', Proceedings of the Royal Society of Medicine, 12, 27-8.

Sturdy S. 1998, 'War as Experiment: Physiology, Innovation and Administration in Britain, 1914-1918: The Case of Chemical Warfare', in Cooter R., Harrison M. and Sturdy S. (eds), War, Medicine and Modernity, London: Sutton, 65-84.

Tanner A. 2002, 'The Spanish Lady Comes to London: The Influenza Pandemic 1918-1919', London Journal, 27, 51-76.

Tansey E. M. 1994, 'Protection Against Dog Distemper and Dogs Protection Bills: The Medical Research Council and Anti-vivisectionist Protest, 1911-1933', Medical History, 38, 1-26.

Thomson A. L. 1973, 1975, Half a Century of Medical Research. Origins and Policy of the Medical Research Council (UK), Vols. 1 \& 2. London: HMSO.

Thomson A. P. 1951, 'A History of the Ferret', Journal of the History of Medicine, VI, 471-80.

Thomson D. and Thomson R. 1933, 1934, 'Influenza', Annals of the Pickett-Thomson Research Laboratory, Parts / \& 2, London: Bailliere, Tindall and Cox.

Tognotti E. 2003, 'Scientific Triumphalism and Learning from Facts: Bacteriology and the "Spanish Flu" Challenge of 1918', Social History of Medicine, 16, 97-110.

Tomkins S.M. 1992, 'The Failure of Expertise: Public Health Policy in Britain during the 1918-19 Influenza Epidemic', Social History of Medicine, 5, 435-54.

Twort F. W. 1915, 'An Investigation of the Nature of Ultramicroscopic Viruses', Lancet, 4 December, 1241-3.

van Helvoort T. 1993, 'A Bacteriological Paradigm in Influenza Research in the First Half of the Twentieth Century', History and Philosophy of the Life Sciences, 15, 3-21.

van Helvoort T. 1994, 'History of Virus research in the Twentieth Century: The Problem of Conceptual Continuity', History of Science, XXXII, 185-235.

Waterson A. P. and Wilkinson L. 1978, An Introduction to the History of Virology, Cambridge: Cambridge University Press.

Weatherall M. 2000, Gentlemen, Scientists, and Doctors: Medicine at Cambridge, 1800-1940, Rochester, NY: Boydell Press.

Wilkinson L. 1978, 'Animal viruses, Veterinary Pathology, and the Formulation of Ideas Concerning Filterable Viruses', Historia Medicinae Veterinariae, 3, 1-15.

Wilkinson L. 2000, 'Burgeoning Visions of Global Public Health: the Rockefeller Foundation, the London School of Hygiene and Tropical Medicine, and the "hookworm connection"', Studies in History and Philosophy of Biological and Biomedical Sciences, 31, 397-407.

Wilkinson L. et al. 2001, Prevention and Cure: The London School of Hygiene \& Tropical Medicine: a 20th Century Quest for Global Public Health, London: Kegan Paul. 